\title{
Isparta bölgesindeki çocukluk çağı zehirlenmelerinin değerlendirilmesi
}

\author{
Evaluation of childhood poisoning in Isparta region
}

\author{
Selim Dereci, Tuğba Koca, Ali Gençer, Filiz Serdaroğlu, Mustafa Akçam
}

\section{ÖZET}

Amaç: Çalışmamızda Süleyman Demirel Üniversitesi Tıp Fakültesi Hastanesi Çocuk Acil servisine başvuran zehirlenme vakalarını retrospektif değerlendirmesi amaçlanmıştır.

Yöntemler: Çocuk acil servisine Temmuz 2013-Temmuz 2014 tarihleri arasında başvuran olgular geriye dönük olarak tarandı. Olguların yaş, cinsiyet, başvuru süreleri, zehirlenmeye neden olan maddeler, zehirlenme şekli, etkenin alınış amacı, semptomlar ve hastaneye yatış durumları değerlendirildi.

Bulgular: Çalışma için yaşları 1-18 yaş arasında (ortalama $8,9 \pm 6,3$ yıl) 82 olgunun dosyası tarandı. Olguların 50 'si $(\% 60,9)$ kız, 32'si $(\% 39,1)$ erkekti. Çocuk acil ünitemize getirilen vakaların \%3,6'sını zehirlenme olguları oluşturuyordu. Zehirlenme olgularının \%51'i 1-5 yaş grubu çocuklardı. İntihar amaçlı zehirlenen 30 hastanın 30'u (\%100) kız ve hepsi 12 yaş üstünde idi. En sık zehirlenme nedeni ilaçlar olup (\%76), bunları insektisitler ve bitkisel maddeler izliyordu. Zehirlenmeye en çok neden olan ilaç grubu grip ilaçları (\%14), antidepresanlar (\%13) ve parasetamol'du (\%12).

Sonuç: Bu çalışmada çocukluk çağı zehirlenmelerinin oyun çağı ve adölosan dönem olmak üzere iki dönemde pik yaptığı tespit edilmiştir. Ailelerin eğitimi ve alınacak basit önlemlerle oyun cağındaki çocukların kaza sonucu olan zehirlenmelerinin büyük ölçüde önlenebileceğini düşünmekteyiz. Ayrıca, ailelerin adölesan yaş grubunda ki kız çocuklarının psikolojilerine uygun davranması ve gerekli durumlarda konusunda uzman olan kişilerden yardım almaları gerekmektedir.

Anahtar kelimeler: Çocukluk çağı, Isparta bölgesi, zehirlenme

\begin{abstract}
Objective: The purpose of this study was to assess the patients who presented with intoxication case to our Children Emergency Department of Süleyman Demirel University Medical Faculty Hospital, retrospectively.
\end{abstract}

Methods: The patients, who were admitted to our children emergency service between the dates July 2013 and July 2014 were searched retrospectively. The age, sex, the admission time, the admission duration, the way of intoxication, symptoms, the items caused intoxication, the aim of taking the item and the hospital stay of the cases were evaluated.

Results: For the study, the files of 82 patients aged from 1 to 18 years (mean $8,9 \pm 6,3$ years) were scanned; 50 $(60.9 \%)$ cases were female, $32(39.1 \%)$ were male. Intoxication cases constituted $3.6 \%$ of all cases admitted to the children's emergency unit over one year period. A high proportion ( $51 \%$ ) of intoxication cases were between 1 and 5 years of age. Thirty of the thirty (100\%) patients that were intoxicated because of a suicide attempt were girls and all of them were over 12 years of age. The most common substance for intoxication was drugs (76\%), followed by insecticides and herbal (6.5\%). Amon the medication, cold relief drugs (14\%), antidepressant (13\%) and paracetamol (12\%) drugs were most common.

Conclusion: Poisoning shows a peak in two periods of childhood and adolescence in this study. We think that accidental ingestion in childhood can be prevented by parents' education and simple precautions in general. In addition, we recommend that families should demonstrate appropriate approaches, especially with regards to the psychology of adolescent girls, and, if necessary, get help from a specialist.

Key words: Childhood, poisoning, Isparta region

Süleyman Demirel Üniversitesi Tıp Fakültesi, Çocuk Să̆lı̆̆ı ve Hastalıkları Anabilim Dalı, Isparta, Türkiye

Yazışma Adresi /Correspondence: Selim Dereci,

Süleyman Demirel Üniv. Tıp Fak., Çocuk Sağlığı ve Hastalıkları AD, Isparta, Türkiye Email: dereciselim@hotmail.com Geliş Tarihi / Received: 15.02.2015, Kabul Tarihi / Accepted: 30.07.2015

Copyright (C) Dicle Tıp Dergisi 2015, Her hakkı saklıdır / All rights reserved 


\section{GíRiş}

Çocukluk çağ1 zehirlenmeleri ülkemizde ve Dünya'da sik görülen bir sağlik sorunudur. Zehirlenme olguları, özellikle çocukluk yaş grubunda acil servise başvuran hastalar arasında önemli bir yer tutar [1]. Zehirlenme, vücuda toksik olan bir maddenin girmesi veya normal dozda toksik olmayan bir maddenin yüksek dozda alınmasıyla insana zarar vermesidir. Zehirlenme bütün yaş gruplarında görülebilmekle birlikte zehir danışma merkezlerine bildirilen vakaların \%50'den fazlasını beş yaş altındaki çocuklar oluşturmaktadır [2-4]. Zehirlenmeye yol açan etkenler yaşanılan bölgeye, toplumun gelenek ve göreneklerine, eğitim düzeyine ve mevsimlere göre değişkenlik göstermektedir [1,5-8]. Bu nedenle her ülkenin, hatta her bölgenin zehirlenme ile ilgili özelliklerinin belirlenip, önlemlerin bu duruma göre planlanması gerekmektedir.

Zehirlenmeler çocukluk çağında önemli ölüm nedenlerinden biri olduğundan, bu vakalarda hızlı bir şekilde alım öyküsü öğrenilmeli, fizik muayenesi dikkatli bir şekilde yapılmalı ve en kötü senaryoyu düşünerek hareket edilmelidir. Zehirlenmeler acil müdahale edilmesi gereken hasta grubudur. Bazen hastalar zehirlenme hikayesi olmadan ensefalopati ya da koma tablosuyla acile gelebilmektedir. Çocukluk çağ 1 zehirlenmeleriyle ilgili yapılmış farklı çalışmalarda görülme sıklığ $1 \% 0,33$ 'den \% 7,6'a kadar değişen farklı oranlarda bildirilmiştir $[9,10]$. Ülkemizde yayınlanan farklı çalışmalarda ise bu oranlar $\% 0,4$ ile $\% 5,5$ arasında değişmektedir [11].

$\mathrm{Bu}$ çalışmanın amacı hastanemiz acil servisine başvuran çocukluk çağ 1 zehirlenmelerini değerlendirmek ve bu konuda alınabilecek önlemlere dikkat çekmektir.

\section{YÖNTEMLER}

Çalışmamız Süleyman Demirel Üniversitesi Tıp Fakültesi çocuk acil servisine Temmuz 2013-Temmuz 2014 tarihleri arasında başvuran zehirlenme vakalarının dosyaları geçmişe dönük incelenerek yapıldı. Hastaların dosya kayıtlarına bakılarak yaş, cinsiyet, başvurduğu mevsim, aldığı madde veya ilaç, karşılaşma yolu, ilaç alımından sonra başvuru anına kadar geçen süre, semptomlar, klinik bulgular, yap1lan müdahaleler, komplikasyonlar, hastanede yatış süresi ve yoğun bakım gereksinimi açısından değerlendirildi.

Zehirlenme etkenleri ilaçlar, besinler, bitkisel maddeler, keyif verici maddeler ve insektisitler olarak gruplara ayrıldı. En büyük grubu oluşturan ilaçlarda kendi içinde analjezik ve antipiretik, antidepresanlar, diğer merkezi sinir sistemi ilaçları, antihistaminikler, antibiyotikler, kardiyovasküler ilaçlar, burun damlası, vitamin-mineral, antiepileptikler ve diğerleri olarak siralandi.

İstatistiksel analizler SPSS 15.0 (Statistical Package For social Science) programı kullanılarak de-

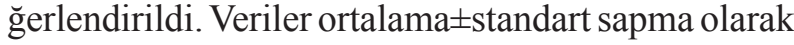
verilmiştir. Bağımsız iki grubun karşılaştırılmasında t testi kullanıldı. Diğer yöntemlerden Mann-Whitney $U$ ve Fisher testlerinden faydalanıldı.

\section{BULGULAR}

Temmuz 2013 - Temmuz 2014 tarihleri arasinda çocuk acil servise başvuran 2291 çocuk vakadan 82 $(\% 3,6)$ olguya zehirlenme tanısı konuldu. Vakaların 50'si $(\% 60,9)$ k1z, 32'si $(\% 39,1)$ erkekti. K1z: erkek oranı 1,56 olarak hesapland1. Başvurularda yaş ortalaması $8,9 \pm 6,3$ yıl olarak tespit edildi. Olgulara yaş gruplarına göre bakıldığında ayrıldığında 42 (\%51) çocuk ile 1-5 yaş arası en fazla vakanın olduğu grupta yaş ortalaması $3 \pm 1,1$ y1l olarak bulundu. Diğer vakalar 5-12 $(7 \pm 1)$ yaş grubunda $3(\% 4)$ ve 12 $18(15,7 \pm 1,3)$ yaş grubunda $37(\% 45)$ vard 1 (Tablo 1). Belirtilen tarihler arasinda acil servisimize zehirlenme vakası olarak bir yaş altı çocuk başvuru gerçekleşmedi.

Yaş gruplarına göre bakıldığında 1-5 ve 5-12 yaş aralığında zehirlenmelerin tamamı kazayla alım şeklinde gerçeklești. Kız: erkek oranı sırasıyla 0,8 ve 0,5 şeklindeydi.

Diğer 12-18 yaş aralığında bulunan 37 vakanın 30'u (\%81) intihar amaçlı, 6'sı (\%16) kazara, 1'i (\%3) ise madde bağımlılığı nedeniyle gerçekleşen zehirlenmeydi. Bu 37 vakanın 30’u kız (\%81) ve kı: erkek oranı 4,3 kat yükseklikle dikkat çekmekteydi.

Zehirlenmelerde alınan maddelerin 63'u (\%76) tıbbı ilaçlar, 5'1 (\%6) insektisit, 3'u (\%4) bitkisel, 3'u (\%4) tiner içimi, 2's1 (\%2) temizlik maddesi, 2's1 (\%2) y1lan sokması, 1 (\%1) naftalın, $1(\% 1)$ bonzai, $1(\% 1)$ oda parfümü, $1(\% 1)$ duş jeli şeklinde görüldü (Grafik 1). Zehirlenme vakalarının 
79'u (\%96) ev ortamında, üçü (\%4) ise ev dışındaki ortamda gerçekleşti. Ev dişında gerçekleşen zehirlenmelerin ikisi yılan sokmasına, kalan bir tanesi ise bonzai alımına bağlı ortaya çıktı. Zehirlenme olgularının 53'u tek, 29'u birden fazla ilaç veya madde alımına bağlı olarak ortaya çıktı.

İlaçlar gruplandırıldığın da grip ilaçları 10 $(\% 14,7)$, antidepresan $9(\% 13,2)$, parasetamol 8 (\%117), non-steroid antienflamatuar ilaçlar (NSAI) $7(\% 10,2)$, aspirin $3(\% 4,4)$, ACE inhibitörleri 3 $(\% 4,4)$, antipsikotikler $3(\% 4,4)$, antiepileptikler $3(\% 4,4)$, metklopropamid $3(\% 4,4)$, psödoefedrin $3(\% 4,4)$, antibiyotikler $2(\% 2,9)$, B 12 vitamini 2 $(\% 2,9)$, demir preparatlar1 $2(\% 2,9)$, antihistaminik $1(\% 1,47)$, betaserc $1(\% 1,47)$, butamirat sitrat 1 $(\% 1,47)$, Ca-D vitamini $1(\% 1,47)$, concerta (Metilfenidat $\mathrm{HCl}) 1(\% 1,47)$, famotidin $1(\% 1,47)$, kolşisin $1(\% 1,47)$, levotroksin $1(\% 1,47)$, montelukast $1(\% 1,47)$, sildenafil $1(\% 1,47)$, tantum sprey $1(\% 1,47)$ ve vastarel $1(\% 1,47)$ olarak siraland 1 (Grafik 2).
Tablo 1. Zehirlenme vakalarının demografik özellikleri

\begin{tabular}{lccc}
\hline Yaş aralığı & $\mathbf{n}(\%)$ & Erkek $(\mathbf{n} / \%)$ & $\mathbf{K} \mathbf{~ z ~}(\mathbf{n} / \%)$ \\
\hline 1-5 yaş & $42(51)$ & $23 / 55$ & $19 / 45$ \\
5-12 yaş & $3(4)$ & $2 / 67$ & $1 / 33$ \\
12-18 yaş & $37(45)$ & $7 / 19$ & $30 / 81$ \\
\hline
\end{tabular}

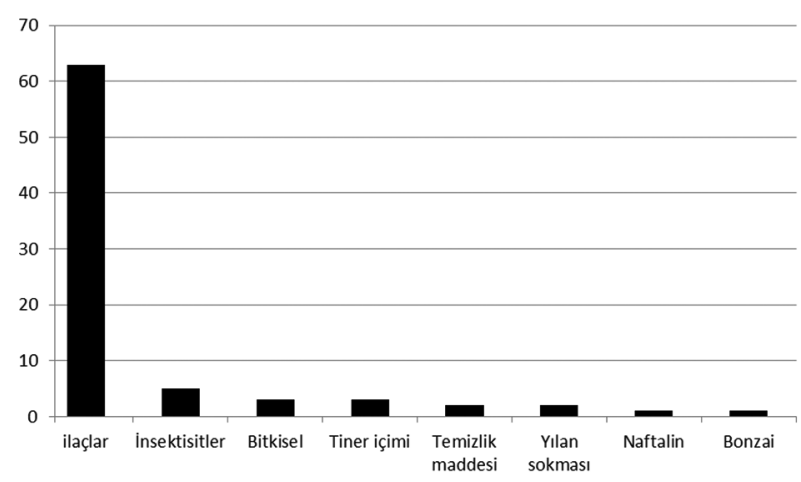

Grafik 1. Zehirlenme vakalarında tespit edilen maddelerin dağılımı

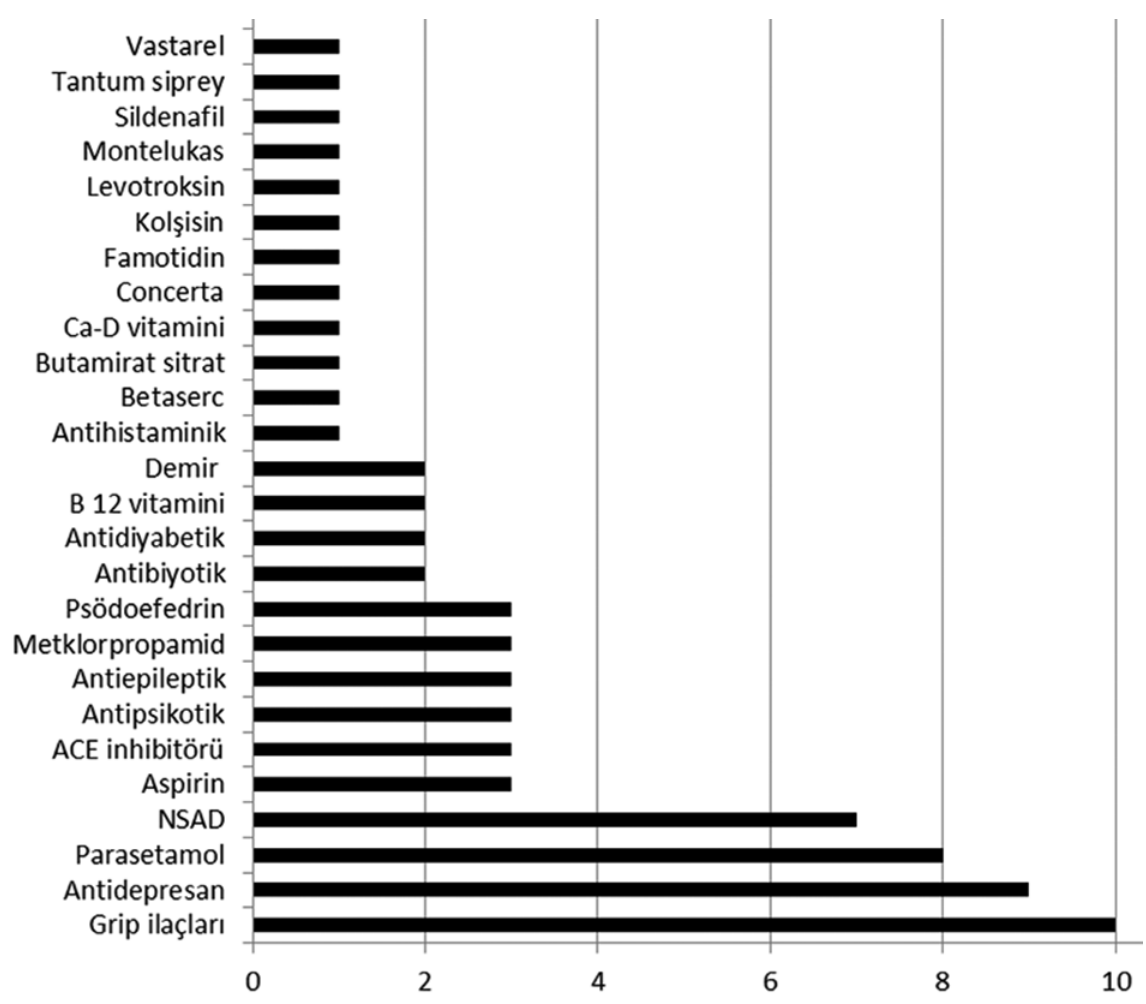

Grafik 2. Zehirlenme olgularında tespit edilen ilaçların dağılımı

Zehirlenmeye yol açan maddelerin üç tanesi hariç hepsi oral yolla alınmıştı. Bu üç zehirlenmenin iki tanesi deri yoluyla ve kalan bir tanesi de inhaler yolla olmuştu. Vakalar zehirlenme gerçekleştikten ortalama 3,5 $\pm 1,8$ (1-7) saat sonra hastanemize ulaşmıştı. Hastanemize direk olarak başvuru sayısı 28 
iken 54 vaka ilimizdeki diğer sağlık kuruluşlarından merkezimize gönderildi.

Vakalarımızın 32'sinde bulantı-kusma, 13'ünde bilinç değişikliği, üçünde karın ağrısı, birinde solunum sıkıntısı vardı. Diğer vakalarda herhangi bir semptom gözlenmedi.

Tedavide toksik madde emilimini engellemek amacıyla 22 vakaya mide lavajı yapıldı, 17 vakaya aktif kömür, 5 olguya antidot olarak $\mathrm{N}$-asetil sistein verildi, 3 hastanın da idrarı alkalinize edildi ve diğer olgulara da semptomatik yaklaşımla izlem yapıldı. Bütün hastalar monitörize edildi ve potansiyel komplikasyonlar (aritmi, hipotansiyon, böbrek ve karaciğer yetmezliği ve benzeri gibi) açısından yakın takip edildi.

Vakaların yıl içinde aylara göre dağglımı Ocak4, Şubat-5, Mart-11, Nisan-13, Mayıs-7, Haziran-11, Temmuz-7, Ağustos-7, Eylül-4, Ekim-3, Kasım-6 ve Aralık-5 vaka olarak tespit edildi (Grafik 3).

Olguların hastanede kalma zamanları yoğun bakımda $1,8 \pm 0,6$, çocuk servisinde $1,2 \pm 0,7$ ve toplamda 2,9 $\pm 1,1$ gün olarak bulundu. Vakalarımızdan dördü yoğun bakımda boş yatak olmaması nedeniyle, bir vakada karaciğer nakline ihtiyacı olduğu için sevk edildi. Olgularımızın takip ve tedavilerinde ölüm vakası olmadı.

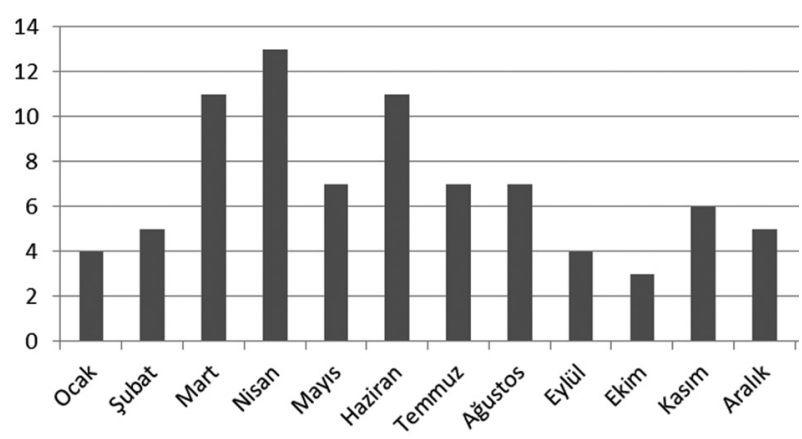

Grafik 3. Zehirlenme vakalarının aylara göre sayısal dağılımı

\section{TARTIŞMA}

Çocukluk yaş grubunda acil servis başvuruları ve hastane yatış nedenlerine bakıldığında zehirlenmeler önemli yer tutmaktadır $[1,2,4,5]$. Zehirlenme olgularında epidemiyolojik özelliklerin bilinmesi erken ve uygun tedavinin yapılması, koruyucu önlemlerin alınabilmesi açısından oldukça önemlidir
$[1,2]$. Çocukluk çağında zehirlenmeler Batı Avrupa ve Kuzey Amerika'da ilaçlar ve ev temizlik ürünleriyle olurken, gelişmekte olan ülkelerde geleneksel ilaçlar, parafin, yılan ve böcek sokmasıyla olmaktadir [12].

Ülkemizde çocukluk yaş grubunda zehirlenme nedeniyle acile başvuru oranları incelendiğinde bölgesel farklılıklar bulunmakla beraber görülme s1klığ1 \%0,33'den \%7,6'a kadar değișen farklı rakamlar bildirilmiștir [9,10]. Erzurum'da \%3,5 [13], İstanbul'da \%0,5, Trabzon'da \%2,7 [14], İzmir'de \%3,3 ve Edirne'de \%2,2 [15] bulunmuştur. Bölgemizde 1995 yılında yapılan çalışmada Isparta ilinde çocukluk çağı zehirlenme oranı \%3,5 olarak bildirilmişti [13]. Bizim çalışmamızda daha önce Isparta'da 1995 yılında yapılan çalışmanın sonucuna benzer \%3,6 oran 1 tespit edildi.

Zehirlenme vakaları ilk beş yaş ve erkek çocuklarda daha fazla görülmektedir. Genellikle kaza sonucu tekli ilaç alımıyla ortaya çıkmaktadır. İkinci sık görülen yaş grubu ise adölesan grubu olup zehirlenmeler kız cinsiyette daha fazla görülmekte, birden çok ilaçla ve daha çok intihar amaciyla olmaktadır [16]. Bizim çalışmamızda da literatüre benzer şekilde en çok zehirlenme 1-5 yaş grubunda (\%51), erkek çocuklarda (kı: erkek oranı 0,8), tekli ilaçla ve kaza sonucunda gerçekleşti. İkinci yoğun grubumuz ise $12-18$ yaş grubunda $(\% 45) \mathrm{k} ı$ cinsiyette (kız/erkek: 4,3) görüldü. Bunların çoğu intihar amaçlı ve birden çok ilaç alımına bağlı olarak görüldü.

Daha önce yapılan çalışmalara bakıldığında intihar amaçlı zehirlenmelerin ortalama \%31 oranında olduğu ve 12 yaş üstünde daha fazla olduğu görüldü [6-8,11,16-19]. Bizim çalışmamızda ise tüm vakalar içinde intihar amaçlı zehirlenmelerin oranı $\% 36$ ve 12 yaş üstünde ise bu oran $\% 81$ olarak tespit edildi. Bu yaş grubunda İntihar amaçlı zehirlenmelerde erkek vakamız yoktu. Daha önce Isparta ilinde yapılan çalışmada sadece iki intihar amaçlı zehirlenme bildirilmiş ve bu sonuç Isparta için çok düşük olarak rapor edilmişti [13]. Şimdiki çalışma sonuçlarına göre maalesef bu sayının literatürle paralel olarak oldukça arttığını görmekteyiz. $\mathrm{Bu}$ yaş grubunda kız çocuklarında intihar olayının daha fazla olmasının nedeni olarak kız çocuklarının toplumda yeri ve rolü, ailede fiziksel ve psikiyatrik hastalık, intihar öyküsü, aile içi çatışmalar, fiziksel 
travmalar, okul başarısızlığı, anne-baba kaybı, parçalanmış aileler, bu dönemde kendi yaşıtı erkeklere göre daha az özgür olmaları, ailelerin kız çocuklara daha fazla koruyucu olmaları ve kız çocukların problemlerini paylaşamamaları olarak bildirilmiştir $[20,21]$. Bu nedenlerden dolayı intihar amaçlı zehirlenme vakaların tümüne hastanede yatarken çocuk psikiyatri tarafindan muayene edilmeleri ve destek almaları sağlanmıştır.

Zehirlenme vakalarının mevsimlere dağılımı bölgesel farklılıklar göstermektedir [1,2,11]. Çalışmamızda zehirlenmeler mevsimsel olarak en fazla ilkbahar ve yaz mevsiminde, aylara bakıldığında ise özellikle mart, nisan, mayıs ve haziran aylarında (\%51) daha fazla olduğu görüldü. Bu sonuç ülkemiz ve Dünya sonuçlarıla benzerlik göstermektedir. Bunun nedeni ise bu mevsimlerde anne ve babalar daha çok bağ, bahçe ve tarım işleriyle meşgul olmaları ve çocukların evde yalnız kalmaları şeklinde açıklanmaktadır [8,18,22].

Hastanemize direkt olarak başvuru sayısı 28 iken 54 vaka ilimizdeki diğer sağlık kuruluşlarından merkezimize gönderilmişti. Bunun nedeni hastanemizin il merkezinden uzak olmasıydı. Çalışmamızda vakalar ilaç aldıktan ortalama 3,5 $\pm 1,8$ [1-7] saat sonra hastanemize ulaşmıştı. Bu sonuç Trakya bölgesi sonuçları $(2,9 \pm 1,7$ saat) ve diğer çalışmalarla benzerlik göstermekteydi [23].

Ülkemizde ve Dünya'da yapılan çalışmalar incelendiğinde çocukluk yaş grubunda zehirlenmenin en s1k nedeninin ilaçlar olduğu görülmektedir $[2,3,24]$. Amerika zehir kontrol merkezi raporlarına göre 1998 yılında 18 yaş altında görülen 1,5 milyondan fazla zehirlenmenin ilaçlara bağlı olduğu ve 56 ölüm vakasının \%66'sının ilaçlara nedeniyle olduğu rapor edilmiştir [25]. Çalışmamızda zehirlenme etkenleri değerlendirildiğinde ilk sırada ilaçlar, ilaçlar içinde de analjezik-dekonjestan-antihistaminik karışımı olan grip ilaçları, ardından antidepresanlar, NSAD, aspirin, ACE inhibitörleri, antipsikotikler ve diğerleri şeklinde sıraland.

Türkiye'de 1998 yılında yeniden yapılandırılıp kurulan Sağlık Bakanlığı, Ulusal Zehir Danışma Merkezi (UZEM) 114 numaralı telefon numarasıyla ücretsiz olarak hizmet vermekte ve Türkiye çapında çoğu vaka bu merkeze bildirilmektedir. Zehirlenmeler hakkında bu merkezdeki önceki verilerden ve uzmanların görüşlerinden faydalanılmaktadır. $\mathrm{Bu}$ merkeze 2008 yılında toplam 133.390 başvuru olmuş, bunlardan 46.894 vaka $(\% 60,14) 18$ yaş altındayd1. Zehirlenmede etken olarak ilk sırada ilaçlar (\%69) yer aldı. İlaçlardan ilk üç sıraya bakıldığında kombine grip ilaçları, parasetamol, antidepresan-antipsikotikler şeklinde sıraland 1 [26]. Hastanemiz çocuk aciline gelen zehirlenme vakalarındaki zehirlenme etkenlerine bakıldığında da benzer ilaç sıralaması olduğu görüldü.

Daha önce Isparta'da 1995 yılında yapılan çalışmada yine ilaçlar ilk sıradaydı ve ilaçlar içinde salisilat (34 vaka, \%18) en s1k etken olarak rapor edilmişti [13]. Bizim çalışmamızda ise salisilat s1ralamada oldukça geride (3 vaka, \%4) kaldı ğ 1 tespit edildi. Bunun nedeni çocukluk yaş grubunda geçmiş yıllarda ateş düşürücü olarak kullanılan aspirinin Reye sendromu riski nedeniyle kısıtlı kullanılması sonucunda salisilat zehirlenmelerinin azalmasıdır [24] . Salisilatın yerine artık parasetamol kullanılmakta ve çalışmamızda da parasetamole bağlı zehirlenme ilaçlar içinde 3 . surada (8 vaka, \%11,7) yer almaktadır. Hacettepe üniversitesi İhsan Doğramacı Çocuk Hastanesinin 20 yıl arayla yaptığ iki çalışmada benzer olarak ilaçlar ilk sırada bildirilmiştir. $\mathrm{Bu}$ iki çalışmanın sonuçlarına bakıldığında ilk dönemde salisilat ilk sırada yer alırken, ikinci çalışmada salisilat oldukça azalarak yerine parasetamolun ön plana çıktığı rapor edilmiştir [29].

Çocukluk çağı zehirlenmelerinde Türkiye'de daha önce görülmeyen keyif verici maddelere bağ11 zehirlenmeler bildirilmekte ve bu durum önemli bir sağlık sorunu olarak karşımıza çıkmaktadır. Zehirlenme vakalarımızdan biri 16 yaşında kız çocuk olup 4 kapak bonzai adlı madde alımı sonucu ile zehirlenmişti. Bonzai sentetik bir madde olup esrarın yol açtı̆g 1 belirtilere benzer etkileri olan psikoaktif bir maddedir. Bu yüzden sentetik esrar olarak da bilinmektedir. İçeriği değişebildiği için etkileri de değişiklikler gösterebilmektedir. Başlıca etkileri; aşırı endişe, algıda değişiklikler, varsanımlar, gevşeme, şüphecilik, kolay yönlendirilebilme, yükselmiş duygu durum, gerçeği değerlendirebilme becerisinde azalma, olayları algilayabilmede sorunlar, aşırı reaksiyon gösterme, bağımlılık, kusma, ağızda kuruluk, çekilme belirtileri, kalp atım hızında artma, çarpınt1, kan basıncında artma, kalp krizi, huzursuzluk ve akıl karışıklığıdır. Esrarda olduğu gibi 
bonzainin de en yaygın kullanım şekli sigara olarak içilmesidir. Bonzaide bağımlılık hızla gelişmektedir $[27,28]$. Bu yazıda tek vakada olsa zehirlenmelere neden olan ve Türkiye'de şu an için Amerika ve Avrupa ülkelerine göre az olan bu maddelere bağl1 zehirlemelere dikkat çekmek isteriz.

Zehirlenmede başlangıç tedavisi acil hayati bulguların tespitinden sonra hava yolu güvenliği, kalp ve dolaşım sürdürülmesini sağlamak olmalıdır. Ardından henüz emilmemiş olan maddelerin emilimini engellemek, atılımını artırmak, varsa antidotunu vermek ve uygun tedavisi sağlamaktır. $\mathrm{Bu}$ amaçla hastanemize gelen zehirlenme vakalarına mide lavaj1 (22 vaka, \%27), ardından aktif kömür uygulaması (17 vaka, \%21), antidot olarak N-asetil sistein (5 vaka, \%6), idrar alkalizasyonu (3 vaka, \%4) ve diğer olgulara da semptomatik yaklaşım (35 vaka,\%43) tedavileri uyguland1. Bu tedavi yaklaş1mımız diğer merkezlerin yaptığı genel tedavi yaklaşımlarıyla benzerlik göstermekteydi. Bütün hastalar monitörize edildi ve potansiyel komplikasyonlar (aritmi, hipotansiyon, böbrek ve karaciğer yetmezliği ve benzeri gibi) açısından yakın takip edildi.

Hastanemiz aciline gelen ve kısa süreli takip edilen 4 vakamız yoğun bakımda yer olmadığı için yoğun bakım şartları olan başka merkezlere sevk edildi. Bir olgumuzda mantar yemeye bağlı takiplerinde karaciğer fonksiyon testlerinin hizla bozulma tespit edilmesi üzerine karaciğer nakli yapılmak üzere sevk edildi ve gittiği merkezde nakil gerçekleştirildi.

Ülkemizde yapılan çalışmalarda genel olarak çocukluk çağ 1 zehirlenmelerine bağl1 ölüm oranları $\% 0,4-5,5$ arasında tespit edilmiştir [11,23,29]. Ça1ı̧̧mamızda mortalite olmaması yüz güldürücüdür. Bunun nedeni çalışma süresinin bir yıl gibi kısa olması ve gelen olguların çoğunun genel durumlarının iyi olması, hızlı müdahalemiz ve vakaların tedaviye iyi cevap vermesiyle şeklinde açıklanabilir.

\section{SONUÇ}

Çocukluk çağı zehirlenmelerinde ilaçlar önemli yer tutmaktadır. Çoğu zaman ihmal ve eğitimsizlik ön plana çıkmaktadır. Çalışmamızın Sonuçlarına göre zehirlemeler en sık 1-5 yaş arasında ve ilk sırada ilaçlara bağlı ortaya çıktığı görüldü. Oyun çağındaki bu dönemde olguları azaltmak için, ilaç ka- paklarının emniyetli bir şekilde olması gerektiğini düşünüyoruz. Bütün çalışmalar zehirlenmelerin en çok ev ortamında olduğunu ortaya koymaktadır. $\mathrm{Bu}$ konuda ailelere düşen en önemli görev ev ortamında çocuklukların zararlı maddelere ulaşmayacağ şekilde tedbirler almaktır.

Ayrıca zehirlenmelerde önemli diğer bir grup olan adölesan kız çocuklarının psikolojilerine uygun yaklaşımlar sergilemeli ve gerekli durumlarda mutlaka uzman kişilerden destek alınmalıdır. Çocuk acil ünitesinde görev alan hekimlerin zehirlenme vakaları hakkında bilgili, donanımlı ve her an hazır olmaları gerekmektedir. Acil servislerde bölgesel epidemiyolojik özelliklere uygun antidot bulundurulmalı ve uygun yoğun bakım şartlarının sağlanmasi gerekmektedir.

Çalışmamızın çocukluk çağı zehirlenmeleriyle ilgili olarak 20 yıl sonra ilimizde yapılan 2. çalışma olması ve ilimiz çevresinde görülen çocukluk çağı zehirlenme olgularının epidemiyolojik ve klinik özelliklerini göstermesi açısından hem bölgemiz hem de ülkemiz açısından önemli olduğunu düşünmekteyiz. Bu bilgiler doğrultusunda konu hakkında daha dikkatli olunması ve ülkemiz genelinde aileler, ilaç üreticileri ve hekimler tarafından alınacak basit önlemlerle ile zehirlenmelerin önlenebileceği düşüncesindeyiz.

\section{KAYNAKLAR}

1. Çıtak A, Yilmaz HL. Pediatrik zehirlenmeler. 1. bask1. İstanbul: İstanbul medikal yayıncılık 2011:1-433.

2. O'Donnell KA, Ewald MB. Poisonings In: Kliegman RM, St.Geme III JW, Stanton BF, Schor NF, Behrman RE. eds. Nelson Textbook of Pediatrics, 19th ed. Philadelphia: WB Saunders Co 2011;250-270.

3. Sarıkayalar F. Çocuklarda zehirlenmeler. Katkı Pediatri Dergisi 2001;22:377-395.

4. Uzel N. Zehirlenmeler. İçinde: Neyzi O, Ertuğrul T. Pediatri Cilt 2, 3. bask1. İstanbul: Nobel T1p Kitabevi 2002;152715267.

5. Kurtoğlu S, Öztürk MA, Ataberk ME: Toksikolojik aciller ve yaklaşımlar. Türkiye Klinikleri Pediatri Özel Sayısı 2006;2:652-662

6. Özdemir R, Bayrakci B, O Tekşam, et al. Thirty-threeyear experience on childhood poisoning. Turk J Pediatr 2012;54:251-259.

7. Yayci N, Pakis I, Karapirli M, et al. The review of autopsy cases of accidental childhood deaths in Istanbul. J Forensic Leg Med 2011;18:253-256.

8. Özdemir D, Yiş U, Kalkan Ş, ve ark. Akut çocukluk çağ zehirlenmeleri. JAEM 2003;1:36-38. 
9. Agarwal V, Gupta A. Accidental poisoning in children. Indian Pediatr 1984;11:617-621.

10. Buch NA, Ahmed K, Sethi AS. Poisoning in children. Indian Pediatr 1991;28:521-524.

11. Naci Öner, Mustafa İnan, Ülfet Vatansever, ve ark. Trakya bölgesinde çocuklarda görülen zehirlenmeler. Türk Pediatri Arşivi 2004;39:25-30.

12. Ellenhorn MJ. The Clinical Approach in Ellenhorn's Medical Toxicology. 2nd edition, Williams-Wilkins, USA 1997;1-46.

13. Tunç B, Örmeci AR, Dolgun A, Karaca H. Isparta Bölgesinde Çocukluk Çağında Zehirlenme Nedenleri. Çocuk sağlığı ve Hastalıkları Dergisi 1995;38:211-218.

14. Türkmenoğlu Y, Gümüşoğlu B, Pekün F, Öztürk H. Çocukluk çağı intoksikasyonlarının retrospektif değerlendirilmesi. 33. Türk PediatriKongresi Kongre Kitabi. Eylül 1997.

15. Kahveci M, Çeltik Ç, Karasalihoğlu S, Acunaş B. Bir üniversite hastanesi acil servisine başvuran çocukluk çağ1 zehirlenmelerinin değerlendirilmesi. Sted 2004;13:19-21.

16. Watson WA, Litovitz TL, Rodgers GC Jr, et al. 2004 Annual report of the American Association of Poison Control Centers Toxic Exposure Surveillance System. Am J Emerg Med 2005;23:589-666.

17. Güzel IŞ, Kibar AS, Vidinlisan S. Çocuk acil servisine başvuran zehirlenme vakalarının demografik özelliklerinin incelenmesi. Genel Tip Derg 2011;21:101-107.

18. Akçay A, Gürses D, Özdemir A. Denizli ilindeki çocukluk çağı zehirlenmeleri. ADÜ Tıp Fakültesi Dergisi 2005;6:15-19.

19. Arapoğlu M, Keskin C, Telhan L. Şişli Etfal Hastanesi 1. Çocuk Kliniği'ne başvuran zehirlenme olgularının değerlendirilmesi. Şişli Etfal Hastanesi Tıp Bülteni 2005;4:41-45.
20. Aktepe E, Kandil S, Göker Z, ve ark. İntihar grişiminde bulunan çocuk ve ergenlerde sosyodemografik ve psikiyatrik özelliklerin değerlendirilmesi. TSK Koyucu Hekimlik Bülteni 2006;5:444-454.

21. Çetin FÇ. Çocuk ve ergenlerde intihar girişimleri. Katkı Pediatri Dergisi 2001;22:450-453.

22. Laminpaa A, Riihimaki V, Vilska J. Hospitalations due to poisonings in Finland. J Clin Epidemiol 1993;46:47-55.

23. Akbay-Öntürk Y, Uçar B. Eskişehir bölgesinde çocukluk çağ1 zehirlenmelerinin retrospektif değerlendirilmesi. Çocuk Sağlığı ve Hastalıkları Dergisi 2003;46:103-113.

24. Riordan M, Rylance G, Berry K. Poisoning in children 3: Common Medicines 2002;87:400-402.

25. Litovitz TL, Klein-Schwartz W, Caravati EM, et. Al. 1998 Annual Report of The American Association of Poison Control Centers Toxic Exposure Surveillance System. Am J Emerg Med 1999;17:435- 487.

26. Özcan N, İkincioğulları D. Ulusal Zehir Danışma Merkezi 2008 Yılı Çalışma Raporu Özeti. Türk Hij. Den. Biyol. Derg 2009;66: Ek 3.

27. Donald G. Medical Toxicology of Drug Abuse: Synthesized Chemicals and Psychoactive Plants. John Wiley \& Sons. Barceloux 2012:910.

28. Thomas G. "Adverse cardiovascular, cerebrovascular, and peripheral vascular effects of marijuana inhalation: what cardiologists need to know". Am J Cardiol Retrieved 2013;113:187-190.

29. Andıran N, Sarıkayalar F. Hacettepe Üniversitesi İhsan Doğramacı Çocuk Hastanesinde son 6 y1lda izlenen akut zehirlenme vakalar1. Katk1 Pediatri Dergisi 2001;22:396408. 